\title{
The verification of prediction and classification ability of selected Slovak prediction models and their emplacement in forecasts of financial health of a company in aspect of globalization
}

\author{
Dusan Karpac ${ }^{1}$, Viera Bartosova ${ }^{2}$ \\ ${ }^{1}$ University of Zilina, The Faculty of Operation and Economics of Transport and Communications, \\ Department of Economics, Univerzitna 1, 01026 Zilina, Slovakia \\ ${ }^{2}$ University of Zilina, The Faculty of Operation and Economics of Transport and Communications, \\ Department of Economics, Univerzitna 1, 01026 Zilina, Slovakia
}

\begin{abstract}
Predicting financial health of a company is in this global world necessary for each business entity, especially for the international ones, as it's very important to know financial stability. Forecasting business failure is a worldwide known term, in a global notion, and there is a lot of prediction models constructed to compute financial health of a company and, by that, state whether a company inclines to financial boom or bankruptcy. Globalized prediction models compute financial health of companies, but the vast majority of models predicting business failure are constructed solely for the conditions of a particular country or even just for a specific sector of a national economy. Field of financial predictions regarding to international view consists of elementary used models, for example, such as Altman's Z-score or Beerman's index, which are globally know and used as basic of many other modificated models. Following article deals with selected Slovak prediction models designed to Slovak conditions, states how these models stand in this global world, what is their international connection to the worldwide economies, and also states verification of their prediction ability in a specific sector. The verification of predictive ability of the models is defined by ROC analysis and through results the paper demonstrates the most suitable prediction models to use in the selected sector.
\end{abstract}

\section{Introduction}

Professional literature refers to business failure issues in different terms: ex-ante financial analysis method, default forecast, early warning systems, financial crisis forecast etc. Irrespective of the variety of individual titles, all methods have a common goal - to identify in a timely manner whether the business entity tends to bankruptcy or financial development. Business failure is an unwanted but existing element of all economies in the world, which can come in various forms and can cause different consequences. In process of globalization, considering the fact, that bankruptcy of one business entity also adversely affects the financial performance of all other entities, that come into closer or even wider 
contact with, it is very important even for whole world economy to predict such situations. These negative influences often comes due to the secondary insolvency resulting failures to meet obligations between individual entities. Based on financial analyses and financial health predictions, remedial action can be taken in due time to mitigate or completely eliminate the risk of bankruptcy.

Various models of financial health predictions were created at different time and space and therefore their application in Slovak conditions can be questioned [1]. The accuracy of prediction models is reduced significantly if the model is used in another industry, another time or in a different business environment compared to the data used to derive the model [2]. There are various arguments against the non-critical usage of the results of foreign prediction models. For example, in the case of Altman's Z-score model, there is a different prediction ability of the market value of equity indicator in the UC economy and in Slovakia $[3,4]$.

The aim of this study is to compare selected Slovak prediction models with standards of Commercial code of Slovakia determining a company in crisis using ROC analysis. The paper explains the connection of the selected models to the global world, and also, there is comparative analysis of their prediction and classification ability and the prediction power to assess financial situation of companies from sector "Data processing, provision of server space on the Internet and related services".

\section{Literature review}

In every business entity, financial management is necessary element for the proper ongoing. In the interest of financial managers, it is the decision to consider the internal situation of the company, but also broad economic environment. This actually means constant checking the financial health of the business entity. In order to identify the level of financial health of the company, prediction models, also called early warning systems, are used. It assesses the health of the company on the basis of complex characteristics, both in terms of past and current developments, as well as in terms of the future development of the entity.

The first one, who dealt with forecasting financial crisis issues was Paul Joseph Fitzpatrick in 1932, who focused on essential differences between successful and failed companies whereby he used the ratio analysis to predict future bankruptcy [5, 6]. Another huge improvement in the field of this area was done by Merwin (1942), when he compared the arithmetic means of selected corporate indicators in prosperous and non-prosperous business. After two decades, Beaver [7] and Altman [8] were considered to be the founders of predicting of financial standing of companies.

Since then, authors and researchers in the field of prediction models have verified dozens of indicators, which, they think, can help predict the insolvency. For these predictors, it is characteristic, that their level in prosperous or non-prosperous enterprises is different as well as the divergent development of indicators long time before the crisis itself [9]. Methods of forecasting a financial situations require the overall financial and economic performance of a firm to be expressed by a current and unambiguous expression $[10,11]$.

Slovak field of scope includes important representatives of prediction models, in 2000 Binkert and Zallay constructed model for business companies, in 2002 Gurcik developed a model for agricultural companies, in 1998 Chrastinova created a model for agricultural companies too [12]. In Slovakia other researchers are dealing with prediction models, such as Hurtosova [13], Lesakova et al. [14], Horvathova \& Mokrisova [15], Gundova [16], Kliestik \& Kocisova \& Misankova [17], Valaskova \& Svabova \& Durica [18], Valaskova et al. [19]. 


\section{Methodology}

For the purpose of comparison and verification of Slovak models in aspect of globalization, we chose three prediction models constructed for Slovak environment, which were formed on the basis of globally known and worldwide used models.

The second step of the methodological process was the selection of a sample of business subjects. The selection file consists of 266 enterprises classified according to SK NACE in class 63110 under the heading "Data processing, provision of server space on the Internet and related services". The category of this economic activity was chosen because of the exponentially growing global need to use virtual space on the Internet as a result of the dynamically evolving time and globalization, the constant upgrading of information technologies and the necessity to know the ability of financial survival of the company in this area.

The source of the relevant data for the analysis of the companies from the sample was the proper financial statements for 2016 drawn from the Financial Statements of the Public Administration Information System of the Slovak Republic, which is operated by the Ministry of Finance of the Slovak Republic and all data are publicly available on the website www.registeruz.sk. After obtaining all the necessary data, we selected the business entities from the sample into two categories, namely "prosperous" and "non-prosperous". When classifying companies, we based on the Commercial Code defining the determination of an enterprise in crisis, together with taking into account the possibility of using other individual criteria used in practice by Slovak enterprises that point to prosperity, we determined the division of the companies through following conditions: Equity/Liabilities < 0,04; Current assets/short-term liabilities < 1; Negative EAT. Business entities that met all three conditions simultaneously were included in the class of non-prosperous subjects and others were designated as prosperous businesses. Data analysis reported 236 prosperous and 30 non-prosperous companies, this standing was considered to be standard benchmark in verifying prediction models.

The next step was in computing financial health of companies in the sample through the selected Slovak prediction models, and then the results were compared to the standard benchmark. Results of this verification were stated in confusion matrix, which gave us data needed for the ROC analysis.

Model of Chrastinová (CH-index) is based on Altman's Z-score model and Beerman's index, and was formed of the data of Slovak agricultural enterprises in the following form [20]:

$$
\mathrm{CH}=0,37 \mathrm{X} 1+0,25 \mathrm{X} 2+0,21 \mathrm{X} 3-0,10 \mathrm{X} 4-0,07 \mathrm{X} 5
$$

where

$\mathrm{X} 1$ = EAT / total capital, $\mathrm{X} 2=\mathrm{EAT} /$ revenues; X3 = Cash flow $/ \mathrm{debt} ; \mathrm{X} 4=\mathrm{debt} /$ revenues; $\mathrm{X} 5$ = debt / total capital.

The classification of the resulting values: $\mathrm{CH}>2.5$ symbolizes healthy financial situation of the company; $-5<\mathrm{CH} \leq 2.5$ neutral zone of unallocated results and if $\mathrm{CH} \leq-5$

unhealthy financial situation of the company.

Model of Gurčík (G-index) is based on Altman's Z-score, Beerman's index and Ch-index and is always focused on companies from agricultural area [21].

$\mathrm{G}=3.412 \mathrm{X} 1+2.226 \mathrm{X} 2+3.277 \mathrm{X} 3+3.149 \mathrm{X} 4-2.063 \mathrm{X} 5$

where

$\mathrm{X} 1$ = retained earnings / liabilities; X2 = EBT / liabilities; X3 = EBT / revenues; X4 = Cash flow / liabilities; X5 = inventory / revenues.

The classification of the resulting values: $\mathrm{G}>1.8$ is for healthy financial situation of the 
company; $-0.6<\mathrm{G} \leq 1.8$ neutral zone of unallocated results and $\mathrm{G} \leq-0.6$ for unhealthy financial situation of the company.

Model of Delina \& Packová is based on Altman's Z-score, Beerman's index and IN05.

$$
\begin{aligned}
& \mathrm{P}^{\prime}=2,86-0,000127 \mathrm{X} 1+0,04851 \mathrm{X} 2+0,2136 \mathrm{X} 3-0,000071 \mathrm{X} 4+0,0001068 \mathrm{X} 5 \text { - } \\
& 0,0006116 \mathrm{X} 6
\end{aligned}
$$

where

$\mathrm{X} 1$ = financial assets - current liabilities / operating costs - depreciation; $\mathrm{X} 2$ = retained earnings - total capital; X3 = EBIT / total capital; X4 = initial capital / total liabilities; X5 = cash flow / liabilities; X6 = EBT / total outputs.

The classification of the resulting values: $\mathrm{P}^{\prime} \geq 2,856$ is for healthy financial situation of the enterprise; $\mathrm{P}^{\prime}<2,856$ is unhealthy financial situation of the enterprise.

\section{Results and discussion}

For the purpose of the paper we calculated financial standing of each company through each selected model. The results were compared to defining of the company in crisis according to Slovak legislation and by confusion matrices of every prediction model we got parameters evaluating the prediction ability of the selected models. These data are presented in following Table 1.

Table 1. Parameters evaluating the prediction ability

\begin{tabular}{|l|r|r|r|}
\hline & Ch-index & G-index & Delina-Packova \\
\hline Type 1 error & $46,67 \%$ & $0,00 \%$ & $0,00 \%$ \\
\hline Type 2 error & $0,00 \%$ & $19,07 \%$ & $3,39 \%$ \\
\hline Sensitivity & $100,00 \%$ & $80,93 \%$ & $96,61 \%$ \\
\hline Specificity & $53,33 \%$ & $100,00 \%$ & $100,00 \%$ \\
\hline Accuracy & $94,74 \%$ & $83,08 \%$ & $96,99 \%$ \\
\hline AUC & $76,70 \%$ & $90,50 \%$ & $98,30 \%$ \\
\hline
\end{tabular}

Considering the results of Ch-index we can see that accuracy is pretty high, even despite the first type of error. The error occurred because the model considered 14 companies, out of 30 companies (which were by Slovak legislation marked as unhealthy), to be financially healthy. As 30 companies out of sample consisted of 266 companies, is really a little number, this wrong categorization didn't influence the accuracy very much. On the other hand, next model, G-index, has weaker accuracy than the Ch-index, even despite of that second type of error is a lot lower than the first type of error of Ch-index. This is because G-index marked 45 companies, out of 236 companies (which were by Slovak legislation considered to be healthy), as unhealthy. The amount of wrongly categorized companies here is bigger than in Ch-index, but error is smaller as it is calculated of much higher number, 236 companies. Third model, Delina-Packova model, reaches only 3,39\% second type of error and the accuracy here is the highest, considering previous models.

As we mentioned above, the dividing companies to "prosperous" and "non-prosperous", in this paper, is highly uneven and that's why we decided to evaluate the prediction and classification ability of the models through another, in this case more appropriate, metrics, which is ROC analysis. 


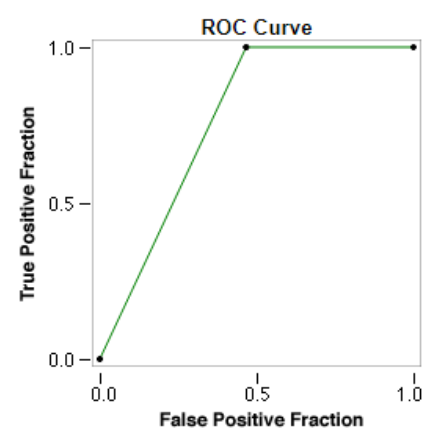

Fig. 1. Illustration of the area under ROC curve for Ch-index

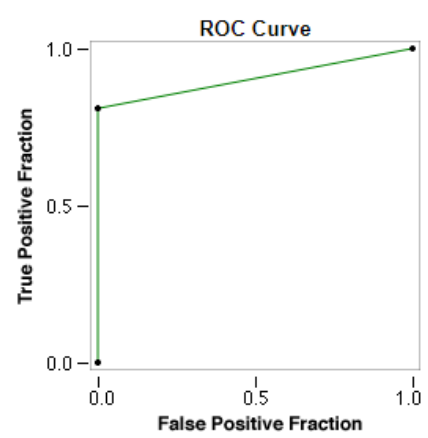

Fig. 2. Illustration of the area under ROC curve for Gurčík model

Fig. 3. Illustration of the area under ROC curve for Delina-Packová model

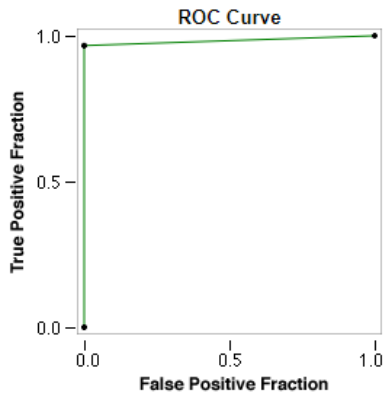

The area under curve (AUC) is better for evaluating imbalanced data sets than accuracy rate as the accuracy would only check how often the actual label overlaps with the benchmark label $[22,23]$. The value AUC is the most common index describing the ROC curve, which is suitable for comparison of various classification models where the whole ROC curve is reduced into one scalar quantity with the usual value between $0,5-1$. If the value is from $0,97-1,00$, then the classifier is considered to be perfect [24].

Accepting all the results of the research of this article, we can say that Delina-Packova model is the most appropriate to be used for predictions of financial health of the companies in Slovakia.

\section{Conclusion}

The financial market as well as the global economy has expanded in recent years by high speed, and, the wider the phenomenon is, the more business opportunities and, therefore, business entities are emerging in the world. However, companies do not always grow and expand, there are many companies that fail and go bankrupt for their businesses for various reasons. Prediction models are supposed to compute financial health of a company and assess if it tends to be prosperous or non-prosperous. This paper's research gives data about verification of prediction and classification ability of three selected Slovak models, which are connected to the global field of predictions through their own constructions - these 
models are formed on basis of other globally used models to forecast financial standing of companies.

Prediction models are generally influenced by wide spectrum of indicators. Because models are usually formed in particular time and for specific field, they don't have to be appropriate for other fields in different time. That is the reason why this study compared three models constructed for Slovak specific field and resulted which is the most suitable for application in the selected sector of the Slovak market.

The model of Radoslav Delina and Miroslava Packova, according to a research conducted in this study in compliance with a particular methodological procedure, has gained value through the ROC curve analysis, which reveals the perfect classification capability. This model was able to correctly determine the prosperity of business entities at $98,3 \%$ and therefore it can be described as the most appropriate model for use in the selected sector, regarding the three models which were taken into account.

This is paper is an outcome of project VEGA: 1/0544/19 Formation of the methodological platform to measure and assess the effectiveness and financial status of non-profit organizations in the Slovak Republic.

\section{References}

1. L. Svabova \& P. Kral. Selection of predictors in bankruptcy prediction models for Slovak companies. In. 10th International Days of Statistics and Economics. Czech Republic, Praha. 1759-1768 (2016).

2. V. Bartosova \& P. Kral. A methodological framework of financial analysis results objectification in the Slovak republic. The European proceedings of social \& behavioural sciences. Malaysia, Mara. 189-197 (2016).

3. P. Adamko \& T. Kliestik. Proposal for a bankruptcy prediction model with modified definition of bankruptcy for Slovak companies. RSEP: international conferences on social issues and economic studies: conference book. Spain, Madrid, 1-7 (2016).

4. T. Kliestik \& V. Dengov. Quantitative approach to risk as a social phenomenon. Proceedings of the 5th International Conference on Applied Social Science. Limasol, Cyprus. 28-33 (2015).

5. K. Zvarikova, E. Spuchlakova \& G. Sopkova. International comparison of the relevant variables in the chosen bankruptcy models used in the risk management. In: Oeconomia Copernicana 145-157 (2017).

6. H. Zhang, H. He \& W. Zhang. Classifier selection and clustering with fuzzy assignment in ensemble model for credit scoring. In: Neurocomputing. 316 210-221 (2018).

7. W. Beaver. Financial ratios as Predictors of Failure. In: Journal of Accounting Research. 4 71-111 (1966).

8. I. E. Altman. Financial ratios, discriminant analysis and the prediction of corporate bankruptcy. The Journal of Finance, 23 589-609 (1968).

9. K. Valaskova \& I. Podhorska. Prediction models in the context of the international environment. In: 17th International Scientific Conference Globalization and It's Socioeconomic Consequences, Zilina. 2792-2800 (2017).

10. F. Zogning. Comparing Financial Systems around the World: Capital Markets, Legal Systems and Governance Regimes. In: Economics, Management and financial markets. 12 43-58 (2017). 
11. J. D. Van Heerden \& P. Van Rensbug. Common Firm-Specific Charasteristics of Extreme Performers on the Johannesburg Securities Exchange. In: Economics, Management and financial markets. 12 25-50 (2017).

12. M. Stachova, P. Kral, L. Sobisek \& M. Kakascik. Analysis of financial distress of Slovak companies using repeated measurements. In. 18th AMSE Applications of mathematics and statistics in economics. Jindrichuv Hradec, Czech Republic. 1-7 (2015).

13. J. Hurtosova. Construction of rating model, tool for assessing the creditworthiness of the company, dissertation thesis. Bratislava: University of economics in Bratislava (2016).

14. L. Lesakova, M. Vinczeova, L. Klement, V. Klementova \& L. Elexe. Corporate planning in small and medium-sized enterprises. Banska Bystrica: Faculty of Economics of University of Matej Bell (2013).

15. J. Horvathova \& M. Mokrisova. Determination of business performance applying modern methods of business performance evaluation. In: Economics Management Innovation. 6 46-60 (2014).

16. P. Gundova. Verification of the selected prediction methods in Slovak companies. In: Acta Academica Karviniensia. 26-38 (2014).

17. T. Kliestik, K. Kocisova \& M. Misankova. Logit and probit model used for prediction of financial health of company. In: Procedia - Economics and finance. 23 850-855 (2015).

18. K. Valaskova, L. Svabova, \& M. Durica. Verification of prediction models in conditions of the Slovak agricultural resort. In: Economics Management Innovation, 9 30-38 (2017).

19. K. Valaskova, T. Kliestik, L. Svabova \& P. Adamko. Financial risk measurement and prediction modelling for sustainable development of business entities using regression analysis. In: Sustainability. 10 (2018)

20. Z. Chrastinova. Methods of economic creditworthiness evaluation and prediction of financial situation of agricultural holdings. Bratislava: VUEPP (1998).

21. J. Miklovicova \& L. Gurcik. The profit and added value creation and development analysis of agricultural companies in selected regions of Slovakia. In: Agricultural economics - Zemedelska ekonomika. 55 329-399 (2009).

22. D. Veganzones \& E. Severin. An investigation of bankruptcy prediction in imbalanced datasets. In: Decision Support Systems. 112 111-124 (2018).

23. T. Le, M. Lee, J. Park \& S. Baik. Oversampling Techniques for Bankruptcy Prediction: Novel Features from a Transaction datasets. In: Symmetry-Basel. 10 (2018).

24. V. Klepac \& D. Hampel. Prediction of bankruptcy with SVM classifiers among retail business companies in EU. In: Acta Universitatis Agriculturae et Silviculturae Mendelianae Brunensis. Mendelova Univerzita in Brno. 64 627-634 (2016).

25. C. Merwin. Financing small corporations in five manufacturing industries. New York: National bureau of economic research (1942). 